\title{
DETERMINATION OF THE LOAD IN DIFFERENT OPERATION IN SEWING MODEL OF WOMAN SHIRT
}

\author{
Milena Trajceva' Sanja Risteski', Vineta Srebrenkoska ${ }^{1}$ \\ ${ }^{1}$ University “Goce Delčev", Štip, Faculty of Technology, Probištip, R.N. Macedonia \\ *e-mail: sanja.risteski@ugd.edu.mk \\ Professional paper \\ UDC: 687.2-055.2:646.6 \\ doi: $10.5937 /$ tekstind 2003029 T

\begin{abstract}
Quality control is a set of steps or guidelines designed to guarantee that a product or service meets certain performance standards. Quality control in textiles is concerned with being certain a product meets performance standards and customer expectations. In this paper one model of woman shirt is observed. For this model a working plan was made and the time that is required to perform the operations of sewing the model was also defined. The total time for each operation, the daily production capacity, the daily capacity per worker and the tact of the group were also calculated. The percentage of load per operation was also defined. The observation in the term of choosing the right operation for the operators was also done..
\end{abstract}

Key words: quality, control, losses, observation.

\section{ODREDIVANJE OPTEREĆENJA U RAZLIČITIM OPERACIJAMA PRILIKOM ŠIVENJA MODELA ŽENSKE KOŠULJE}

\begin{abstract}
Apstrakt: Kontrola kvaliteta je skup koraka ili smernica dizajniranih tako da garantuju da proizvod ili usluga ispunjavaju određene standarde performansi. Kontrola kvaliteta tekstila bavi se sigurnošću da proizvod ispunjava standarde performansi i očekivanja kupaca. U ovom radu je razmatran jedan model ženske košulje. Za ovaj model napravljen je radni plan i određeno je vreme koje je potrebno za obavljanje operacija šivenja modela. Takođe se izračunava ukupno vreme za svaku operaciju, dnevni kapacitet proizvodnje, dnevni kapacitet po radniku i takt grupe. Takođe je definisan procenat opterećenja po operaciji. Obavljeno je i posmatranje u smislu izbora prave operacije za operatere.
\end{abstract}

Ključne reči: kvalitet, kontrola, troškovi, posmatranje.

\section{INTRODUCTION}

Quality means customer needs is to be satisfied. Failure to maintain an adequate quality standard can therefore be unsuccessful, but maintaining an adequate standard of quality also costs effort. There are a number of factors on which quality fitness of garment industry is based such as - performance, reliability, durability, visual and perceived quality of the garment. In the garment industry quality control is practiced right from the initial stage of sourcing raw materials to the stage of final finished garment. Quality control is generally understood as assessing for quality after products have already been manufactured and sorted into acceptable and unacceptable categories. Apparel garments, accessories, and other textile products are assessed for quality in the preproduction phase, during production, and with a final inspection after the product has been completed.

Textile industries are increasingly faced with the demand for small orders and various items. This conditions a flexible system of operation, good knowledge of the technological process of making clothing items and proper deployment of operations in the production line. Technology sheet is applied for workload time adjustment, and process plan is developed for a known spatial connection. 
To survive in this comparative world the textile industry should work more efficient to improve production and the quality of the garments to sustain in the enormous competitive market. The sustainability and profitability of garment industry is governed by the productivity of that industry. Garment manufacturing involves number of operations carried out at different spots by the operators. All these activities need to be performed in synchronized, planned and timely to achieve desired productivity. There are various practices and methods applied in industries to improve productivity of the industries [1,2].

The deployment of workers and the preparation of a plan for the technological process is prepared by the head of the brigade/production line. He strives for efficient preparation of the plan, which means to pass a ready-made product through the sewing process quickly as possible and without defects. The head of the production line prepares a special plan for each individual product, but taking care of:

$\checkmark$ Existing Machine Park.

$\checkmark$ Work ability of each worker.

$\checkmark$ Connection of operations.

$\checkmark$ Training of workers to perform certain operations.

Also, is necessary to know which worker, depending on his/her work ability, at which operation to be placed. The goal is to provide a proper load on the working place, which can lead to more organized work for better production of a suitable garment for shaping, and avoid any set-back in the production process $[3,4,5]$.

One of the possible installation systems of working places in a production line is with the transport trolleys. In the production line, machines are usually arranged on two sides, the transport system works with the help of moving trolleys that move freely, starting from the first operation to the last one.

When sewing a woman's shirt, usually the first operation is interphase ironing. The worker irons the garment pieces that will be further sewn. The worker arranges them on a trolley and moves it to the next working place. The next worker performs the appropriate operation, arranges the sewn pieces on the trolley and pushes it to the next worker. Thus, the stroller is moved to the last worker, respectively to the last sewing operation. This is a known as a very effective system because workers do not waste time getting up, taking and returning garment pieces to perform their operation. This allows them to pay more attention to the task at hand and contribute to greater performance.

At the same time, two or even three spare trolleys can be found in one working place, which means that operator is supplied with work for a certain period of time.

By applying this system of trolleys, workers are dependent on each other, depending on how the trolley moves through the production line [6].

The head of the brigade needs to know the workers well so, that he can assign easier and faster operations to workers who perform slower and have less experience, and give more complex operations to those who are more capable of perform it. In order to avoid set-backs in the production line, due to insufficient execution of workers in some of the operations, the head of the production line prepares a plan for each work order according to the retention time of the garment pieces in one working place in minutes. According to the calculated flow, it determines the operations of the workers depending on their ability, taking into account that they can achieve the norm, and at the same time they are not overloaded $[7,8]$.

\section{EXPERIMENTAL}

The model of women shirt that is subject of this paper is shown below (Figure 1). The shirt is produced in production line with a system of trolleys. The shirt is made of $100 \%$ PES.

The model has open collar, 2 darts on the front and 2 darts on the back. On the right front part there is a batten on which buttons and brackets are placed, and on the left front part there is an outer pocket with epaulet, button and button hole. On the back there is a plate. The sleeves are short with upward folded cuff and epaulet buttoned.

Table 1 shows a working plan for the design of a female model of shirt (size from 38 to 50).

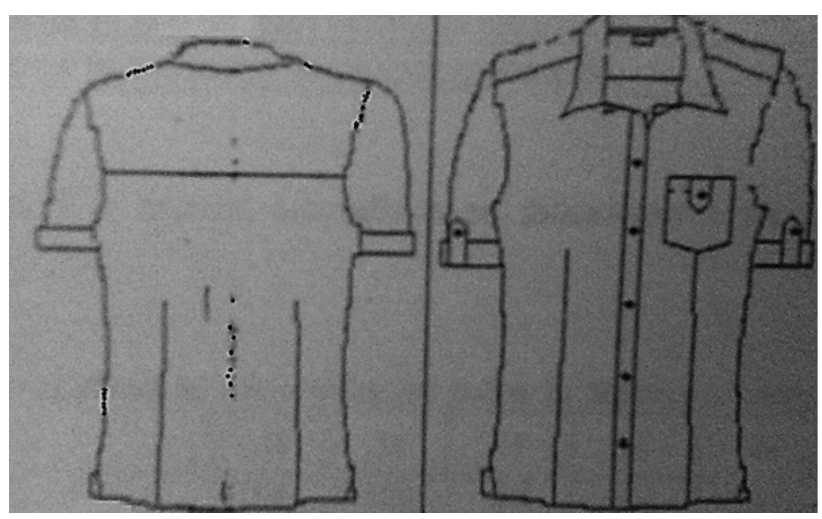

Figure 1: Technical sketch of the women shirt (front and rear part) 
Table 1: Working plan for the model of female shirt

\begin{tabular}{|c|c|c|c|c|c|c|c|c|c|c|}
\hline Ser.Number & $\begin{array}{c}\text { Fabric } \\
\text { color }\end{array}$ & Model & \multicolumn{8}{|c|}{ Size/ number of apparel products } \\
\hline \multirow{2}{*}{1} & \multirow{2}{*}{ White } & \multirow{2}{*}{ K1895 } & 38 & 40 & 42 & 44 & 46 & 48 & 50 & $\sum$ \\
\hline & & & 48 & 60 & 75 & 75 & 75 & 75 & 50 & 468 \\
\hline
\end{tabular}

The machine arrangement for sewing this model of women's shirt in the production line is shown bellow (Figure 2).

The basic requirements that are need to be fullfilled for the quality level of a model are:

$\checkmark$ The side seams should be faced to the back of the shirt.

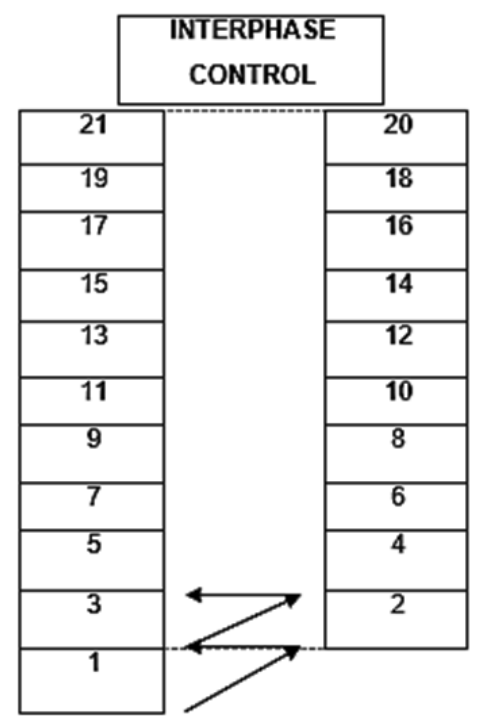

$\checkmark \quad$ The pocket should be in the middle and the left side dart.

$\checkmark \quad$ The sleeve epaulettes should be positioned in the middle of the sleeve parallel to the middle of the shoulder.

$\checkmark$ The epaulette of the pocket should be positioned in the middle of the pocket.
$1,2,3,4,5,6,7,8,9,10,11,15,16,17$ и 18

Regular machine (RM)

$12,13,14,19,20$

Special machine (SM)

21 - Hand work

Figure 2: The machine arrangement for sewing the model of women's shirt in the production line

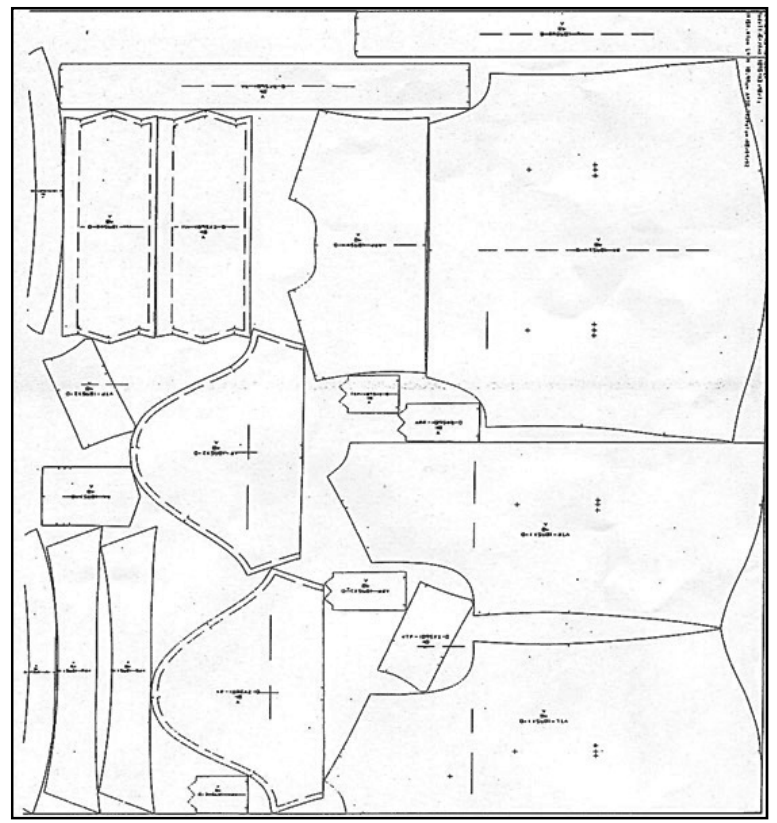

Figure 3: Appereance of cutting layout of the presented model 
Table 2: Plan of technological operations, norm, time of production and working equpment for the given model of women shirt

\begin{tabular}{|c|c|c|c|c|}
\hline $\begin{array}{c}\text { Ser. } \\
\text { Number }\end{array}$ & Name of operation & $\begin{array}{l}\text { Time (min) } \\
\text { /piece }\end{array}$ & $\begin{array}{l}\text { Norm/ } \\
\text { Piece }\end{array}$ & $\begin{array}{c}\text { Working } \\
\text { equipment }\end{array}$ \\
\hline 1 & Collar assembling and insert thread & 1,05 & 400 & $\mathrm{RM}$ \\
\hline 2 & Flip and cut collar & 0,54 & 777 & HW \\
\hline 3 & Collar upper stitch + closure around & 1,09 & 385 & $\mathrm{RM}$ \\
\hline 4 & Measure and cut collar & 0,15 & 2800 & HW \\
\hline 5 & Collar stitch & 0,49 & 857 & $\mathrm{RM}$ \\
\hline 6 & Gouge, mark collar, assembling collars & 1,4 & 300 & $\mathrm{RM}+\mathrm{HW}$ \\
\hline 7 & Flip and cut collar base & 0,42 & 1000 & HW \\
\hline 8 & Ironing finished collar with collar base & 0,21 & 913 & Press cloth \\
\hline 9 & Cutting collar along her length & 0,58 & 2000 & $\mathrm{HW}$ \\
\hline 10 & Fastens two-sided label & 0,84 & 724 & $\mathrm{RM}$ \\
\hline 11 & Ironing batten with gauge & 2,1 & 500 & Iron \\
\hline 12 & Sewing, closing batten on the front part & 1,05 & 200 & RM \\
\hline 13 & Upper stitch on stitched batten & 1,05 & 400 & $\mathrm{RM}$ \\
\hline 14 & Measure, stitch darts along front part & 1,14 & 400 & $\mathrm{RM}+\mathrm{HW}$ \\
\hline 15 & Measure, stitch darts along rear part & 0,30 & 400 & $\mathrm{RM}+\mathrm{HW}$ \\
\hline 16 & Overlock pocket & 0,26 & 3000 & SM \\
\hline 17 & Sewing batten on pocket and insert epaulette & 0,38 & 1400 & RM \\
\hline 18 & Stitch pocket (not ironed) from above & 1,29 & 1615 & RM \\
\hline 19 & Ironing and forming the pocket & 0,59 & 1105 & Iron \\
\hline 20 & Marking and sewing pocket & 1,29 & 325 & $\mathrm{RM}+\mathrm{HW}$ \\
\hline 21 & Stitch and mark pocket epaulette & 0,59 & 711 & $\mathrm{RM}+\mathrm{HW}$ \\
\hline 22 & Cutting and flip pocket epaulette & 0,33 & 1272 & $\mathrm{HW}$ \\
\hline 23 & Upper stitch pock et epaulette backwards & 0,54 & 777 & $\mathrm{RM}$ \\
\hline 24 & Measure and cut pocket epaulette & 0,14 & 3000 & $\mathrm{HW}$ \\
\hline 25 & Sewing plate on the rear part with overlock & 0,42 & 1000 & SM \\
\hline 26 & Upper stitch plate (rear part) & 0,58 & 724 & RM \\
\hline 27 & Sewing the plate on the rear part with overlock & 0,55 & 763 & SM \\
\hline 28 & Upper stitch plates (front part) & 0,62 & 677 & RM \\
\hline 29 & Cuff ironing along middle & 0,35 & 1200 & Press cloth \\
\hline 30 & Stitch epaulets to the sleeve & 1,18 & 355 & $\mathrm{RM}$ \\
\hline 31 & Cut and flip sleeve epaulette & 0,65 & 646 & HW \\
\hline 32 & Upper stitch sleeve epaulette backwards & 1,08 & 388 & RM \\
\hline 33 & Measure and cut front sewn epaulette & 0,21 & 2000 & $\mathrm{HW}$ \\
\hline 34 & Assembling shoulders with overlock & 0,55 & 763 & SM \\
\hline 35 & Sewing sleeve with overlock & 0,96 & 437 & SM \\
\hline 36 & Sewing cuff on sleeve and inserting epaulets & 1,05 & 400 & RM \\
\hline 37 & Overlock sewn cuffs & 0,42 & 1000 & SM \\
\hline 38 & Fastens sleeves before assembling & 0,56 & 750 & RM \\
\hline 39 & Side assembling & 0,87 & 482 & SM \\
\hline 40 & Fastens sleeve & 0,56 & 750 & RM \\
\hline 41 & Overlock fringe, measure and cut & 0,78 & 477 & SM \\
\hline 42 & Overlock side slits & 0,42 & 1000 & SM \\
\hline 43 & Hem shirt & 1,4 & 300 & RM \\
\hline
\end{tabular}




\begin{tabular}{|c|l|c|c|c|}
\hline 44 & Fastens slits & 0,62 & 677 & RM \\
\hline 45 & Hem slits & 1,2 & 350 & RM \\
\hline 46 & Collar stitch + cut neck slit & 1,56 & 269 & RM \\
\hline 47 & Collar closure + upper stitch & 1,83 & 229 & RM \\
\hline 48 & Sewing 5 + 1 button & 0,72 & 583 & SM \\
\hline 49 & Making 6 button holes & 0,68 & 617 & SM \\
\hline 50 & Marking button position on pocket & 0,14 & 3000 & HW \\
\hline 51 & Sewing pocket button & 0,12 & 3500 & SM \\
\hline 52 & Making pocket button hole & 0,14 & 3000 & SM \\
\hline 53 & Marking button position on sleeves & 0,28 & 1500 & $\mathrm{HW}$ \\
\hline 54 & Sewing buttons on sleeves & 0,24 & 1750 & $\mathrm{SM}$ \\
\hline 55 & Making button holes on sleeves & 0,28 & 1500 & $\mathrm{SM}$ \\
\hline 56 & Fastening paddings & 0,52 & 507 & $\mathrm{SM}$ \\
\hline 57 & Cleaning extra thread & 1,20 & 250 & $\mathrm{HW}$ \\
\hline Total time & & $39,1139 m i n$ & & \\
\hline
\end{tabular}

RM - Regular machine, HW - Hand work, SM- Special machine

\section{RESULTS AND DISCUSSION}

The obtained results for the given model are shown below.

$\checkmark$ Time for manual operation: $\sum_{t} H W=4,27 \mathrm{~min}$

$\checkmark$ Time for regular machine: $\sum_{t} R M=24,06 \mathrm{~min}$

$\checkmark$ Time for special machine: $\sum_{t} S M=7,81 \mathrm{~min}$

$\checkmark$ Time for Inter phase ironing: $\sum_{t} I P I=2,03 \mathrm{~min}$.

Taking into account this calculation the total time is $39,0 \mathrm{~min}$

$\checkmark \quad$ The daily production capacity (Cd) of a female shirt for 7 working hours shift (Tr) for 21 workers $(R)$ is: $C_{d}=226,15 \mathrm{~min}$

$\checkmark$ The daily capacity per worker $C d r=10,76$

$\checkmark$ The tact of the group $\mathrm{Rg}=1,85$.

The percentage of load per operation is calculated and for operation 1 (table 2 ) is: So $=56 \%$. On the same way percentage of load is calculated for all remain operations.

$$
\mathrm{S}_{\mathrm{o}}=\frac{t_{o} 1}{R_{g}} * 100=\frac{1,05}{1,85} * 100=56,0 \%
$$

This model of women's shirt is complicated for sewing, because it has a large number of construction parts (figure 3). Also the model was from the newest collection and for the first time was sewn in this operation line. The working places in this brigade were set according to the transport trolley system for simpler models, in this case it would be necessary to relocate jobs 16, 25 and 27 so that the trolleys would always move only forward. However, this was not done, because it was considered that it is simpler for the trolley from the overclock machine jobs 12,13 and 14 to go back to the working places to perform operations 16 , 15 and 27. It is noted that performing operations 12 and 13 required less time, and that operation $12 \mathrm{com}$ bines two operations. It is also noted that due to the complexity of the model and a large number of operations, certain jobs are significantly burdened (working place 16) as well as that the manual work - thread cleaning is increased.

From the the obtained results it is noted that, working places such as: Hem shirt, fastens slits and hem slits are very loaded with percent of load $(S=$ $174 \%$ ). Also the operation such as: Marking and sewing pocket, upper stitch plate (rear part) and upper stitch plates (front part) shown high percent of load $(S=134 \%)$.

The percent of load over $100 \%$ was also obtained in the following operations: Sewing cuff on sleeve and inserting epaulets, fastens sleeves before assembling and fastens sleeve with the load of $117 \% .116 \%$ of load was obtained in the operacions such as: Collar upper stitch + closure around and measure, stitch darts along front part. In the operations: Flip and cut collar base, Fastens two-sided label and Measure, stitch darts along rear part, the load was $111 \%$. In the opearions: Measure and cut collar, collar stitch, gouge and mark collar, assembling collars, Ironing finished collar with collar base, Ironing batten with gauge, Ironing 
and forming the pocket and measure and cut pocket epaulette the load was $110 \%$, and $109 \%$ of load was noticed in the operations such as: Sewing $5+1$ button, marking button position on pocket, sewing pocket button, marking button position on sleeves, sewing buttons on sleeves and fastening paddings.

Lower than $100 \%$ load was obtained in the folowing operations (serial number according to the Table 3): $97 \%$ of load for the operations $9,46,47$. The load for the operations: $6,25,27,34,35,37,39,41$ and 42 was $92 \%$. For the operations: $30,31,32$ and 33 the load was $84 \%$, and for the operations: $13,18,22,23,17$ and 14 the load was $70 \%$. In the operation cleaning thread the obtained load was $65 \%$, and the lowest percent of load (59\%) was noticed in the operations such as: Making 6 button holes, making pocket button hole and making button holes on sleeves.

Also, has been observed that workers have a lower percentage of performance at the beginning of the working day, and over time they achieve full work efficiency. Reduced performance is observed if workers do not feel well, perform a certain operation for the first time, change the working operation, but sometimes deliberately slow down the work to reduce the set norm.

\section{CONCLUSION}

In the production line with a system of trolleys, a new model of woman shirt was produced.

Time for manual operation $\left(\sum_{\mathrm{t}} \mathrm{HW}=4,27 \mathrm{~min}\right)$, time for regular machine $\left(\sum_{\mathrm{t}} \mathrm{RM}=24,06 \mathrm{~min}\right)$ time for special machine $\left(\sum_{\mathrm{t}} \mathrm{S} M=7,81 \mathrm{~min}\right)$, time for Inter phase ironing $\left(\sum_{\mathrm{t}} I P I=2,03 \mathrm{~min}\right)$ and the total time $\left(\sum t=39,0\right)$ $\min$ ) were obtained.

The daily production capacity $\left(C_{d}=226,15 \mathrm{~min}\right)$, the daily capacity per worker $\left(C_{\mathrm{dr}}=10,76\right)$, the tact of the group $(\mathrm{Rg}=1,85)$ and the percentage of load per operation ( $\mathrm{So}=56 \%$ ) were also calculated. From the obtained results can be concluded that some of the working places shown high percent of load compared with others working places.

The operations such as: Hem on the shirt, fastens slits and hem slits are very loaded with percent of load $(S=174 \%)$.

The operation such as: Marking and sewing pocket, upper stitch plate (rear part) and upper stitch plates (front part) also had shown high percent of load $(S=134 \%)$.

The operations sewing cuff on sleeve and inserting epaulets, fastens sleeves before assembling and fastens sleeve shown load of $117 \%$.
$116 \%$ of load was obtained in the operacions such as: Collar upper stitch + closure around and measure, stitch darts along front part.

In the operations: Flip and cut collar base, Fastens two-sided label and Measure, stitch darts along rear part, the obtained load was $111 \%$.

In the opearions: Measure and cut collar, collar stitch, gouge and mark collar, assembling collars, Ironing finished collar with collar base, Ironing batten with gauge, Ironing and forming the pocket and measure and cut pocket epaulette the load was 110 $\%$, and $109 \%$ of load was noticed in the operations such as: Sewing $5+1$ button, marking button position on pocket, sewing pocket button, marking button position on sleeves, sewing buttons on sleeves and fastening paddings.

Lower than $100 \%$ load was obtained in the folowing operations (serial number according to the Table 3): $97 \%$ of load for the operations $9,46,47$. The load for the operations: $6,25,27,34,35,37,39,41$ and 42 was $92 \%$. For the operations: $30,31,32$ and 33 the load was $84 \%$, and for the operations: $13,18,22,23,17$ and 14 the load was $70 \%$. In the operation cleaning thread the obtained load was $65 \%$, and the lowest percent of load (59\%) was noticed in the operations such as: Making 6 button holes, making pocket button hole and making button holes on sleeves.

With the observation of the results was also noted that workers have a lower percentage of performance at the beginning of the working day, and over time they achieve full work efficiency. Reduced performance is observed if workers do not feel well, perform a certain operation for the first time, change the working operation, but sometimes deliberately slow down the work to reduce the set norm. For successful staffing of the production line it is necessary to know the skills of the workers and their capabilities to perform various operations. Operators who are low skilled should be deployed to operations with longer manufacturing time, and skilled and fast operations workers with shorter manufacturing time.

For successful garment production, for the realization of the products plans and accuracy of given delivery deadlines, especially in conditions when is working with small work orders, the good organization of work it is necessary, and that can be achieved with right arrangement of operators in the production line. The obtained results of the percent of the load in all operations of sewing the model of woman shirt can help in distribution the work to operators through a prior assessment of their working skills. 


\section{REFERENCES}

[1] Дембовски Г. (2003). Проектирање во конфекциско производство. ТМФ - Скопје.

[2] Wahid, K. M. (2016). Implementation of modern garment planning tools \& techniques in garment industry of bangladesh. International Journal of Engineering and Advanced Technology Studies, 4(3), 31-44.

[3] Krishna, B. Misra. (2008). Quality Engineering and Management (Handbook of Perform ability Engineering. Springer Verlag, London, 157-170.

[4] Juran, JM., Gryna Jr. FM. (1980). Quality planning and analysis. 2nd edition, McGraw-Hill, New York.

[5] Чепујноски, Ѓ. Чепујноска, В. (1993). Управување со квалитетот во практиката. Скопје.
[6] Juan C. Hiba. (1998). Improving working conditions and productivity in the garment industry: Practical ideas for owners and managers of small and medium-sized enterprises. Geneva, International Labour Office.

[7] Sorak S. Urošević S. Sorak M. (2017). Uticaj ponašanja rukovodilaca - menadžera na uspešnost poslovanja preduzeća tekstilne industrije u Banjoj Luci. Tekstilna industrija, 65(2), 40-47.

[8] Ќортошева, С. (2002). Анализа на трудот во конфекциско претпријатие. Интерна скрипта, ТМФ-Скопје.

Rad primljen: 07.08.2020.

Rad prihvaćen: 27.08.2020. 